\title{
The Expression of Surface Tissue Factor Apoprotein by Blood Monocytes in the Course of Infections in Early Infancy
}

\author{
R. P. A. RIVERS, H. E. J. CATTERMOLE, AND I. WRIGHT \\ Department of Paediatrics, St. Mary's Hospital Medical School, London, England
}

\begin{abstract}
The expression of surface tissue factor procoagulant activity and its shedding by blood monocytes can be induced by several stimuli. Few of these defined situations, other than the presence of bacteria and their toxins, are commonly present in the young human infant. In this study, measurements were made of the percentage of monocytes expressing surface tissue factor apoprotein (TFA) in blood taken from babies in the early weeks of life. Mononuclear cells were separated from blood in an environment free of detectable endotoxin. After exposure to a polyclonal rabbit antibody raised to purified brain TFA and subsequent exposure to a fluorescin-labeled murine anti-rabbit IgG, the cell fluorescent activity was analyzed by flow cytometry. The percentage of monocytes showing strong fluorescence was determined. In every instance when systemic bacterial infection was present, more than $60 \%$ of the monocytes examined showed fluorescence indicative of the presence of surface TFA. In a single case of fungal Candida septicemia, none of the monocytes was positive. More than $60 \%$ of cells were found to be positive in certain instances where infection was highly probable but not proven. Positive cells were found in three cases of isoimmune hemolytic disease of the newborn, as had been anticipated from previous studies, whereas less than $25 \%$ of monocytes derived from babies in the absence of discernible infection or isoimmune hemolytic disease expressed surface TFA $(p<0.001)$. These findings provide insight into a possible mechanism of coagulation activation in sepsis and may prove to be a useful predictor of the presence of infection or endotoxemia in young infants. (Pediatr Res 31: $567-573,1992$ )
\end{abstract}

Abbreviations

TF, tissue factor

TFA, tissue factor apoprotein

IHD, isoimmune hemolytic disease

IEF, isoelectric focusing

DOC, sodium deoxycholate

TF is a phospholipid complex, which as a cofactor enhances the protease activity of factor VIIa toward its substrates factors $X$ and IX (1). Expression of TF activity and of TFA antigen on the surface of monocytes follows active intracellular synthesis,

Received October 17, 1990; accepted December 19,1991.

Correspondence and reprint requests: Dr. R. P. A. Rivers, Department of Paediatrics, St. Mary's Hospital Medical School, Queen Elizabeth the Queen Mother Wing, St. Mary's Hospital, South Wharf Road, London W2, 1 NY.

Supported by the National Fund for Research into Crippling Diseases and by the St. Mary's Save the Baby Fund. The work was carried out in the Sam Segal Perinatal Unit, St. Mary's Hospital. which can be induced by a variety of stimuli; these include bacterial endotoxins (2-5), soluble immune complexes (6-10), antibody-coated erythrocyte and antibody-coated latex particle complexes $(11,12)$, lectins $(13,14)$, lymphokines $(15,16)$, and viruses (17). Antigen-specific monocyte procoagulant responses have been shown to be enhanced by the collaborative participation of $\mathrm{T}$ lymphocytes via both lymphokine and $\mathrm{T}$ cell contact pathways of induction (18-24). Serum and platelets enhance the response to endotoxins $(25,26)$. The activated complement components $\mathrm{C} 3 \mathrm{~b}$ and $\mathrm{C} 5$ can also induce TF synthesis (27), and exposure of monocytes to low $\mathrm{pH}$ causes TF to become available on the cell surface (28). The assembly of the factor X-activating activity on the monocyte surface is enhanced by the endogenous production of factor VII by human monocytes (29).

That monocyte generation of TF activity requires protein and RNA synthesis has been established by the observations that both cycloheximide and actinomycin $D$ block this monocyte response $(8,14,30,31)$. Studies that have reported on the influence of possible intermediaries in the endotoxin-induced TF response have demonstrated moderate inhibition by L-epinephrine, prostaglandin E1 and dibutyril-cAMP $(28,31,32)$. Marked inhibition is produced by prostaglandin E1 and by CAMP when they are combined with phosphodiesterase inhibitors when immune complexes or protein derivatives of Calmette-Guæerin bacillus are used as stimulants (33).

In the clinical setting (34), increased monocyte TF activity has been demonstrated using coagulation assay methods after splenectomy in trauma patients (35), after other surgical procedures (36), and in individuals with Mediterranean fever (37), rheumatic disease and circulating soluble immune complexes (38), bacterial endocarditis (39), or meningococcal infection (40).

Although monocytes taken from pregnant women in the 3 rd trimester have been shown to contain less thromboplastin activity and to generate less activity after endotoxin stimulation than those from a control group of nonpregnant women (41), the monocytes of neonates, on endotoxin stimulation, generate amounts of activity similar to those of normal adults when measurements are made on cell suspensions containing similar monocyte concentrations. Comparisons of intracellular thromboplastin activity of endotoxin-stimulated monocytes from neonates and from adults have not been reported.

In this study, circumstances arising in young babies under which surface monocyte TFA might be expressed were investigated. Particular interest was taken in babies being screened for the presence of infection. Monocytes were examined for the expression of surface TFA using a fluorescent antibody technique, the results being compared with measurements of $\mathrm{TF}$ expression on monocytes from a group of noninfected infants.

\section{MATERIALS AND METHODS}

Infant populations. Monocytes from two populations of infants were studied for the presence of tissue antigen expression. The 
first comprised babies born by elective cesarean section who were studied at birth (group 1, $n=4$ ) and babies born vaginally in the absence of any evidence of previous or intercurrent infection (group II, $n=9$; ages at day of study, 3-76 d); the second population included infants in whom risk factors for infection existed at birth or in whom there were nonspecific clinical signs such as tachypnea or apneic episodes, which can be associated with infection. In some, a diagnosis of infection was confirmed (group III, $n=10$ ); in others, the diagnosis, although suspected clinically, was not proven (group IV, $n=13$ ). Four babies in whom infection had been proven previously were studied beyond the immediate period of their infection $(5-25$ d) to obtain information on the possible duration of monocyte TFA expression.

Blood samples $(0.25 \mathrm{~mL})$ were withdrawn from saline-flushed arterial catheters or by direct venipuncture of the umbilical vein at delivery or from a peripheral vein after Betadine (Napp Laboratories, Cambridge, UK) surface cleansing. The study as conducted had the approval of the Hospital District Ethics Committee, although repeat studies during a suspected infection were not approved and therefore could not be performed. The permitted sample volume was $0.25-0.3 \mathrm{~mL}$.

Infection screening of infant population. All infants, with the exception of the four who were studied after infection episodes, were evaluated for evidence of bacterial infection before any antimicrobial administration, although in two instances the babies' mothers had received i.v. antimicrobials before delivery and within $24 \mathrm{~h}$ of the screening of the newborn infants. Investigations used in support of the categorization "infected" were a Creactive protein level $>10 \mathrm{mg} / \mathrm{L}$ with or without an immature/ total neutrophil index $>0.2$. Some babies in the second population of at-risk babies were subsequently proven to be infected on the basis of one or more of the following: 1) blood culture and/or cerebrospinal fluid culture positive, 2) urine streptococcal antigen positive, 3) endotracheal aspirate culture positive in association with radiologic evidence of parenchymal lung involvement, and 4) a combination of positive supportive investigations of infection in association with clinical and radiographic evidence of necrotizing enterocolitis. Other babies in this population who had presented with clinical features compatible with infection were found to have positive supportive investigations but negative blood, cerebrospinal fluid, and urine bacterial cultures; others proved to be culture- and ancillary test- negative. These included babies developing increasingly frequent apneic episodes "of prematurity" and babies with tachypnea in association with one or more of the following: meconium aspiration, delayed clearance of fetal lung fluid, surfactant deficient respiratory distress syndrome, and congenital heart disease.

Statistical methods. The nonparametric Mann-Whitney U test was applied to the results obtained for the group with proven infection and to the results from those with no evidence of infection.

TFA antibody: antigen purification. Heptane/butanol powders of human brain frozen at $-70^{\circ} \mathrm{C}$ for less than 6 mo were produced according to the procedures of Nemerson (42). Two $g$ of these powders were dissolved in $25 \mathrm{~mL}$ of $1.250 \% \mathrm{DOC}$ (43) in veronal buffer $(2.2 \mathrm{~g}$ barbital, $14.0 \mathrm{~g}$ Na barbital in $4 \mathrm{~L})$, pH 8.6 (44). The product was centrifuged to remove coarse material (17 600 $\times g$ for $30 \mathrm{~min}$ ) and recentrifuged to clarify. The supernatant was then adjusted to $\mathrm{pH} 9.6$ with $1 \mathrm{M} \mathrm{NaOH}$.

Gel filtration. The supernatant from the heptane/butanol powders was applied to a Sephacryl S-300 superfine gel filtration column (Pharmacia $60 \times 2.5 \mathrm{~cm}$; Pharmacia LKB Biotechnology $\mathrm{AB}$, Uppsala, Sweden) and was eluted with $0.625 \%$ DOC in veronal $\mathrm{pH} 8.6$ at a rate of $15 \mathrm{~mL} / \mathrm{h}$. Four-mL fractions were collected and assayed for TF procoagulant activity (28).

Preparative $I E F$. Biologically active fractions from the gel filtration were combined and prepared for IEF by dialyzing against $0.2 \%$ Triton X-100 (Sigma Chemical Co., St. Louis, MO) to remove the DOC. The IEF was performed on agarose gels
(Ultrodex, LKB) in the $\mathrm{pH}$ range 5-8 (Ampholine, LKB). After the electrophoresis, the gel was fractionated, the fractions being eluted through small filtration columns with $0.625 \%$ DOC in veronal buffer. The fractions were then passed through a short desalting column $(25 \times 2.5 \mathrm{~cm})$ to remove ampholytes. Samples drawn from the fractions were relipidated to reconstitute activity before assaying for TF procoagulant activity. The active fractions were subjected to affinity chromatography using anti-human antiserum (Behring Diagnostics, Hoechst UK, Hounslow, UK) coupled to CNBr-activated Sepharose (Pharmacia) (44) to remove any residual contaminating plasma protein traces.

Assay of procoagulant activity. TF activity was determined by a one-stage unactivated partial thromboplastin time (28). Relipidation of apoprotein was carried out according to the procedure of Gonmori and Takeda (44). The nonrelipidated apoprotein was stored in aliquots at $-70^{\circ} \mathrm{C}$.

Antibody production. Nonrelipidated purified apoprotein was dialyzed against veronal buffer $(\mathrm{pH} 8.6)$ and precipitated from solution by addition of ammonium sulfate (final concentration $60 \%$ saturation). Three $\mathrm{mg}$ of the washed precipitate were redissolved in Freund's complete adjuvant (Difco Ltd., Detroit, MI) and injected into rabbits (New Zealand Whites, 3-4 kg). Further injections of $0.3 \mathrm{mg}$ in adjuvant were given biweekly for $3 \mathrm{mo}$. The rabbits were bled by direct peripheral arterial cannulation to prevent contamination by rabbit TF into endotoxin-free plastic tubes.

Sera were stored at $-70^{\circ} \mathrm{C}$. The IgG fraction was precipitated (33.3\% saturation of ammonium sulfate) and resuspended in veronal buffer/saline ( $\mathrm{pH} 7.35)$. The solution was then assayed for biologic inhibitory activity by measuring the degree of procoagulant inactivation produced in a preparation of brain TF (Manchester comparative reagent, human brain origin). The antibody was further purified by affinity chromatography to TFA covalently bound to Sepharose 4B using CNBr (45). The IgG fraction was passed through a small affinity column $(10 \mathrm{~mL})$ and washed with veronal buffer/saline ( $\mathrm{pH} 7.35)$. The anti-TF IgG was eluted from the column with $1 \mathrm{M}$ glycine (adjusted to $\mathrm{pH} 3$ with $\mathrm{HCl}$ ) and was dialyzed against PBS. An Ouchterlony precipitin gel showed lines of identity with the immunizing apoprotein antigen, with brain TF (Manchester reagent), and with TF derived from endotoxin-stimulated monocytes. No precipitin lines were obtained between the anti-TF antibody and normal human plasma. Inhibitory activity of purified antibody was determined by incubating equal volumes of human brain-derived TF (Manchester reagent) diluted 1 in 4000 in veronal buffer with the $\mathrm{IgG}$ at $37^{\circ} \mathrm{C}$; residual procoagulant activity was assayed in an unactivated partial thromboplastin time (28). Immunoblot analysis of crude and purified TFA was performed on $12 \%$ polyacrylamide gel, transferred to nitrocellulose, and reacted with a 1 in 2 dilution of antibody.

All solutions were endotoxin free as determined by chromogenic limulus assay (limit of sensitivity 0.01 endotoxin units/ mL; Whittaker M. A. Bioproducts, Walkersville, MD) and were prepared and stored in endotoxin-free containers.

Blood collection and mononuclear cell preparation. Whole blood $(0.25 \mathrm{~mL})$ was collected into a $1.5-\mathrm{mL}$ polypropylene microtube (Sarstedt, Numberecht, Germany) containing $0.1 \mathrm{~mL}$ $\mathrm{Na}$ citrate/citric acid (three parts $0.1 \mathrm{M} \mathrm{Na}$ citrate, two parts 0.1 $\mathrm{M}$ citric acid) anticoagulant and $0.65 \mathrm{~mL}$ normal saline. The 1 $\mathrm{mL}$ of saline/blood/anticoagulant was layered onto $0.5 \mathrm{~mL}$ Ficoll/Hypaque [modification of Boyum (46); Pharmacia, Steling Research Laboratories, Surbiton-on-Thames, UK] and centrifuged at $400 \times g$ for $40 \mathrm{~min}$ at $4^{\circ} \mathrm{C}$. The layer of mononuclear cells was aspirated and washed two times in cold PBS. Samples were processed immediately after blood withdrawal.

Labeling of monocyte surface TF. The separated mononuclear cells were resuspended in $0.25 \mathrm{~mL}$ of purified anti-TF antibody $(20 \mu \mathrm{g} / \mathrm{mL}$ final concentration) for $45 \mathrm{~min}$ at room temperature. The cells were then washed two times in PBS. Anti-rabbit IgG labeled with fluorescein isothiocyanate (Nordic 1/20 dilution; 
Nordic, Tilburg, The Netherlands) was then added, and the cells were incubated for an additional $45 \mathrm{~min}$. The cells were again washed two times in PBS. If cells were to be stored at $4^{\circ} \mathrm{C}$ overnight, the pellet was resuspended in $10 \%$ formaldehyde in PBS. A positive control was obtained by adding endotoxin (Escherichia coli, Difco 0111:B4) in a final concentration $10 \mu \mathrm{g} /$ $\mathrm{mL}$ to an aliquot of the initial blood sample; unstimulated cells from freshly obtained blood of a normal adult served as a negative control. An additional negative control was prepared by substituting PBS for anti-TF antibody in the first incubation of the patient sample; activity detected in this sample was due to nonspecific binding of murine anti-rabbit Ig fluorescein isothiocyanate. Labeled cells could be stored in the dark at $4^{\circ} \mathrm{C}$ for 24 $\mathrm{h}$ without loss of label.

A Coulter EPICS model V (Coulter Electronics, Inc., Hialeah, FL) was programmed to analyze the cell activities. The monocyte population was gated on forward angle light scatter and $90^{\circ}$ light scatter, and the fluorescence of the first 5000 cells of each sample was measured. The fluorescence of monocytes in the negative control patient sample was subtracted from the fluorescence obtained in the anti-TF Ig-exposed patient sample and the results expressed as the percentage of cells with fluorescent activity above $\log 30$ when the log integral green voltage is set at $850 \mathrm{~V}$.

\section{RESULTS}

TFA antibody. The biologic inhibitory activity of the isolated $\mathrm{IgG}$ fraction from the immunized rabbits is indicated in Figure 1 using a commercial source of human-derived brain TF. The results presented are the mean values at each incubation time point. Each assay was performed in duplicate and the results from two experiments were combined. The range of values for each given time point analyzed was within $\pm 2 \mathrm{~s}$ of the mean value shown. Control incubations with veronal buffer and with serum from an unimmunized rabbit are illustrated. The presence of control sera enhances the procoagulant activity of the TF preparation when compared with the veronal buffer samples.

The antibody recognized a single $53-\mathrm{kD}$ band consistent with the reported size of purified human TF (Fig. 2) on the immunoblot analysis.

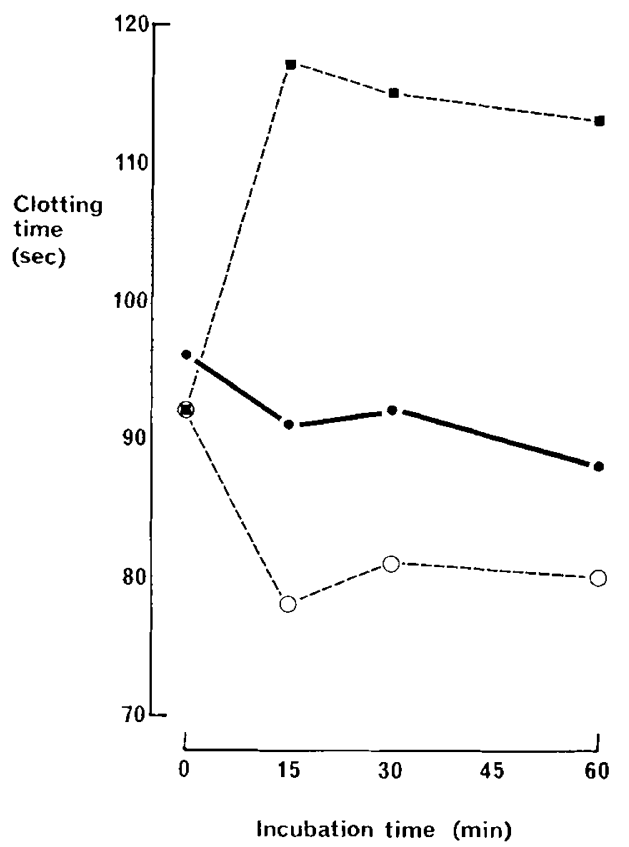

Fig. I. Inhibition of $\Upsilon F$ procoagulant activity by $\operatorname{IgG}$ fraction from serum of rabbit immunized against purified TFA as evidenced by an increase in the duration of the clotting time. $\mathbf{\square}, \mathrm{TF}+\mathrm{IgG}$ from immunized rabbit. $\mathrm{O}, \mathrm{TF}+\mathrm{IgG}$ from nonimmunized control rabbit. $\bullet, \mathrm{TF}+$ veronal buffer.

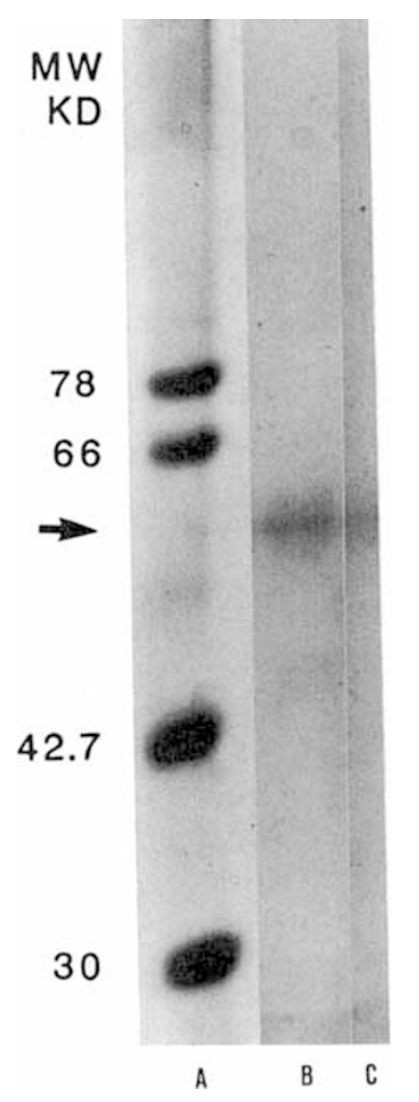

Fig. 2. Immunoblot of crude and purified human brain TFA. Prestained molecular weight standards (lane $A$ ), crude TF extract (lane $B$ ), and purified TFA (lane $C$ ) reacted with anti-TF antibody.

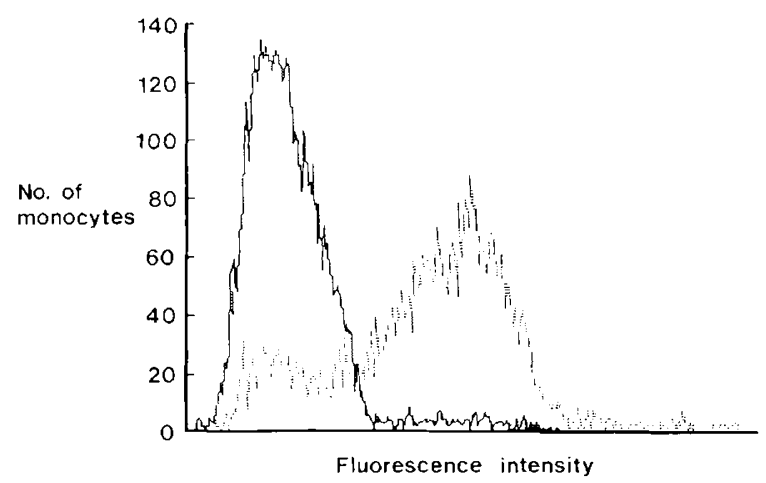

Fig. 3. Monocyte fluorescence after exposure to fluorescin-labeled murine anti-rabbit IgG (-_) (nonspecific binding) and to fluorescinlabeled murine anti-rabbit $\operatorname{lgG}$ when preceded by rabbit anti-TFA $(\ldots)$ (strongly positive monocytes) by flow cytometry on cells from a baby with Listeria monocytogenes septicemia.

The gating positions of TF-expressing, newborn-derived monocytes and adult-derived monocytes were similar, and no loss of activity followed storage for $12-24 \mathrm{~h}$ in the dark. The pattern of nonspecific second antibody binding is seen in Figure 3 (low level fluorescence) along with the binding to previously coupled anti-TFA antibody on monocytes from a baby with Listeria monocytogenes infection (high level fluorescence).

The photomicrograph is of a fluorescent antibody-positive monocyte from a baby with coagulase-negative staphylococcal septicemia (Fig. 4)

Monocvte TFA detection. The highest percentage of monocytes expressing TFA as evidenced by their levels of fluorescence in the cord-obtained samples from the group I babies was $24(n=$ 4 , values $11,20,22$, and $24 \%$, Fig. 5 , column I). Of the group II babies, also designated as negative for infection, with the excep- 


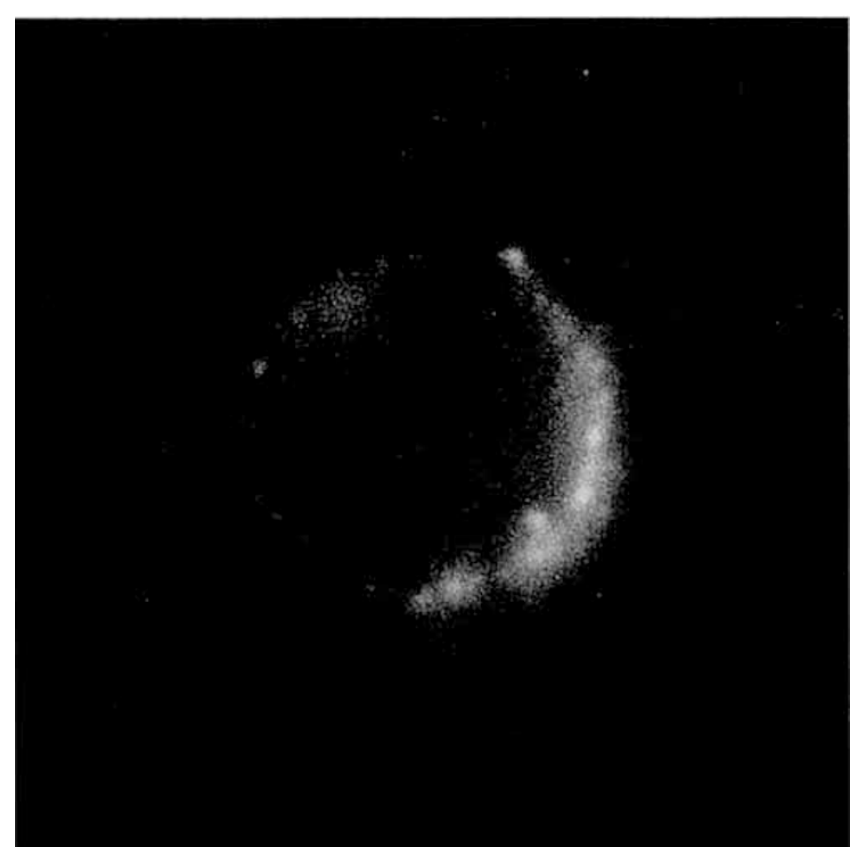

Fig. 4. Photomicrograph of a TFA-expressing monocyte from a baby with coagulase-negative staphylococcal septicemia, labeled by fluorescent antibody technique.

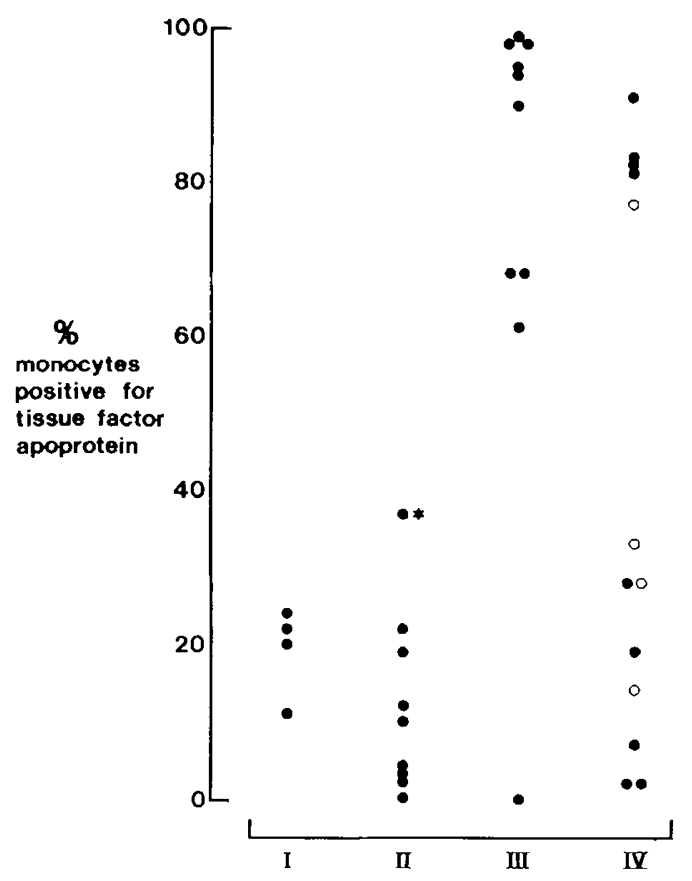

Fig. 5. The values are shown for the percentage of monocytes positive for TFA in the samples from the elective cesarean section babies, cord blood origin (column I), from babies designated negative for infection (column II), from babies with proven infection (column III), and from those in which infection was strongly suspected (column IV). In the latter group, those studied within $4 \mathrm{~d}$ of the infection screening tests are represented by filled circles, and those studied more than $4 \mathrm{~d}$ after screening are represented by open circles. In column $I I$, the asterisk marks the result of the monocytes from the baby with isoimmune Rhesus (RhD) blood group incompatibility.

tion of one, the highest value was $22 \%(n=9$, values $37,22,19$, $12,10,4,3,2$, and $0 \%$; Fig. 5 , column $I I)$. The baby in whom $37 \%$ of monocytes were positive was affected by Rhesus blood group incompatibility; his erythrocytes were Coombs positive. Two neonates affected by isoimmune anti-A blood group incom- patibility and without evidence of infection were studied subsequently. In one, $74 \%$, and in the other, $92 \%$ of the analyzed monocytes were positive. In group III with proven infection, in which sampling was carried out within $4 \mathrm{~d}$ of the positive bacterial/fungal diagnosis (four within $1 \mathrm{~d}$, five within $2 \mathrm{~d}$, and one within $4 \mathrm{~d}$ ), nine of the 10 had a high percentage of their monocytes strongly positive for TFA. These values are significantly different from those obtained for the babies with no evidence of infection $(p<0.001)$. One baby who was blood culture positive for the yeast Candida pseudotropicalis had no strongly positive monocytes demonstrable from her blood. In a single baby with cytomegalovirus infection, but with a coagulasenegative staphylococcal septicemia, $99 \%$ of monocytes were positive (Fig. 5, column III, Table 1).

In four babies who had previously been established as infected on the basis of positive bacterial isolates $19,5,13$, and $25 \mathrm{~d}$ before monocyte testing ( $J, K, L$, and $M$ in Table 2), the percentage of the monocyte population positive for TFA was 99 , 97,70 , and 33, respectively, at a time when each appeared free of infection, the C-reactive protein and band/total neutrophil index having returned to normal or near normal values at the time of monocyte sampling. Prolonged persistence of monocyte TFA surface expression can therefore be seen to occur.

In group IV, the subgroup strongly suspected of being infected, there were 13 babies. They were all symptomatic at the time of infection screening and were studied at a median age of $16 \mathrm{~d}$ (range 2-46 d); nine were studied within $4 \mathrm{~d}$, and the remainder were studied at $>4 \mathrm{~d}$ (range 5-9 d) after the initial infection screening investigations. Among the nine studied within $4 \mathrm{~d}$ of infection screening, high percentages of monocytes were positive in four $(91,83,82$, and $81 \%)$, a lower percentage was positive in one $(28 \%)$, and the percentages found positive in four were within the range found in noninfected infants $(0,0,7$, and $19 \%)$. In the four studied beyond $4 \mathrm{~d}$ from the screening investigations $(5,6,6$, and $9 \mathrm{~d})$, one had $77 \%$ of the monocytes strongly positive, two had lower percentages positive (33 and $28 \%$ ), and one had a level in the range of noninfected infants (14\%; Fig. 5 , column IV).

\section{DISCUSSION}

There are two principal reasons for our interest in quantifying monocyte TF expression in early infancy: the TF pathway of coagulation activation might be an important mechanism in the initiation of the abnormal proteolysis frequently described in neonatal sepsis and in those affected by severe Rhesus blood group incompatibility, and TF detection might prove to be a useful indicator of the presence of infection or endotoxemia in its own right. This is of particular interest in the young infant, where diagnosis is notoriously difficult but where many of the potential stimuli for TF expression are likely to be rarely encountered. Immune complex disorders are one such group that might be anticipated to give rise to monocyte TF expression. IgG-erythrocyte complexes have been shown in vitro to induce monocyte TF expression (11), and in vivo induction has also been reported (12); their presence may have induced the positivity in the baby with Rhesus IHD and in the babies with anti-A IHD. Another potential complicating factor is the reported frequency of endotoxemia in cord blood at delivery (47). We have not observed percentages of positive monocytes greater than $24 \%$ in four cord-derived samples taken at birth from apparently noninfected babies. However, it is possible that this level of monocyte positivity is due to low concentrations of endotoxin, as have been reported.

The possibility of a positive result being an artifact due to in vitro TF elaboration by monocytes is unlikely because, even if monocytes that have been slightly stimulated before sampling were to respond more readily than normal monocytes to low concentrations of endotoxin in vitro, it is improbable that endotoxin levels, which are so low as to be unmeasurable, would 
Table 1. Details of babies positive for infection and investigated for monocyte TF antigen within $4 d$ from time of positive culture*

\begin{tabular}{|c|c|c|c|c|c|c|}
\hline Case & $\begin{array}{c}\mathrm{G} \\
(\mathrm{wk})\end{array}$ & Organism isolated & Features of sepsis & $\begin{array}{c}\mathrm{CRP} \\
(\mathrm{mg} / \mathrm{L})\end{array}$ & $\mathrm{I} / \mathrm{TI}$ & $\begin{array}{l}\text { MTFA- } \\
\text { positive } \\
\text { cells (\%) }\end{array}$ \\
\hline A & 39 & $\begin{array}{l}\text { Listeria monocytogenes } \\
(1 \text { and } 2)\end{array}$ & Isolated from blood but not CSF & $\begin{array}{c}148 \\
(5)\end{array}$ & $\begin{array}{r}0.43 \\
(5)\end{array}$ & $\begin{array}{l}98 \\
(5)\end{array}$ \\
\hline B & 32 & $\begin{array}{l}\text { Klebsiella } \\
(40,41,42)\end{array}$ & Isolated from CSF but not from blood & $\begin{array}{l}96 \\
(42)\end{array}$ & $\begin{array}{c}0.41 \\
(42)\end{array}$ & $\begin{array}{c}68 \\
(42)\end{array}$ \\
\hline $\mathrm{C}$ & 25 & $\begin{array}{l}\text { Staphylococcus epidermidis } \\
\text { (26) }\end{array}$ & Isolated from blood & $\begin{array}{c}60 \\
(28)\end{array}$ & $\begin{array}{c}0.34 \\
(28)\end{array}$ & $\begin{array}{l}90 \\
(28)\end{array}$ \\
\hline $\mathrm{D}$ & 40 & $\begin{array}{l}\text { Group B streptococcus } \\
\text { (12) }\end{array}$ & Isolated from blood and CSF & $\begin{array}{l}296 \\
(13)\end{array}$ & ND & $\begin{array}{c}61 \\
(13)\end{array}$ \\
\hline $\mathrm{E}$ & 36 & & $\begin{array}{l}\text { Clinical and radiographic evidence of } \\
\text { NEC } \\
\text { (2) }\end{array}$ & 37 & $\begin{array}{l}0.5 \\
(4)\end{array}$ & 94 \\
\hline $\mathrm{F}$ & 26 & & $\begin{array}{l}\text { Clinical and radiographic evidence of } \\
\text { NEC }\end{array}$ & 82 & 0.63 & 95 \\
\hline & & & $(19)$ & (24) & (19) & (19) \\
\hline G & 34 & & $\begin{array}{l}\text { Group B streptococcal antigen in } \\
\text { urine } \\
\text { Marked respiratory distress } \\
\text { Chest x-ray compatible with pneu- } \\
\text { monia } \\
\text { (2) }\end{array}$ & 63 & 0.1 & 68 \\
\hline $\mathrm{H}$ & 29 & $\alpha$-Hemoloytic streptococcus & $\begin{array}{l}\text { Maternal amnionitis } \\
\text { Marked respiratory distress } \\
\text { Organism isolated from tracheal aspi- } \\
\text { rate } \\
\text { Chest } x \text {-ray compatible with pneu- } \\
\text { monia }\end{array}$ & 148 & 0.78 & 98 \\
\hline & & (1) & & (2) & $(2)$ & (2) \\
\hline I & 25 & Candida pseudotropicalis & $\begin{array}{l}\text { Seen on a buffy smear of peripheral } \\
\text { blood and then isolated from blood }\end{array}$ & 47 & 0.59 & 0 \\
\hline & & (32) & & (33) & (30) & (32) \\
\hline I & 25 & $\begin{array}{l}\text { CMV } \\
(69-76)\end{array}$ & $\begin{array}{l}\text { Isolated from urine and tracheal } \\
\text { washings }\end{array}$ & 50 & 0.64 & 99 \\
\hline & + & $\begin{array}{l}\text { S. epidermidis } \\
(69)\end{array}$ & On blood culture & (70) & (70) & $(70)$ \\
\hline
\end{tabular}

${ }^{*} \mathrm{G}$, gestation at birth; CRP, C-reactive protein; I/TI, immature:total neutrophil index; MTFA, monocyte tissue factor antigen; CSF, cerebrospinal fluid; NEC, necrotizing enterocolitis; ND, not determined; and CMV, cytomegalovirus. Numbers in parentheses indicate day of age on which investigation result was obtained.

Table 2. Details of babies positive for infection and investigated for monocyte TF antigen when more than $4 d$ from time of positive culture* $^{*}$

\begin{tabular}{|c|c|c|c|c|c|c|}
\hline Case & $\mathrm{G}(w \mathrm{k})$ & Organism isolated & Features of sepsis & $\begin{array}{c}\mathrm{CRP} \\
(\mathrm{mg} / \mathrm{L})\end{array}$ & $\mathrm{I} / \mathrm{TI}$ & $\begin{array}{l}\text { MTFA- } \\
\text { positive } \\
\text { cells(\%) }\end{array}$ \\
\hline $\mathrm{J}$ & 40 & $\begin{array}{l}\text { Group B streptococcus } \\
\text { (3) }\end{array}$ & Isolated from blood and CSF & $\begin{array}{l}89 \\
(3)\end{array}$ & $\begin{array}{r}0.45 \\
(4)\end{array}$ & $\begin{array}{c}70 \\
(16)\end{array}$ \\
\hline $\mathrm{K}$ & 26 & $\begin{array}{l}\text { Staphylococcus epidermidis } \\
\text { (2) }\end{array}$ & Isolated from blood & $\begin{array}{c}52 \\
(21)\end{array}$ & $\begin{array}{r}0.67 \\
(21)\end{array}$ & $\begin{array}{c}33 \\
(27)\end{array}$ \\
\hline $\mathrm{L}$ & 30 & $\begin{array}{l}\text { Group B streptococcus } \\
\text { (1) }\end{array}$ & Isolated from blood & $\begin{array}{l}35 \\
(2)\end{array}$ & $\begin{array}{r}0.61 \\
(2)\end{array}$ & $\begin{array}{l}97 \\
(6)\end{array}$ \\
\hline M & 39 & $\begin{array}{l}\text { Listeria monocytogenes (case A) } \\
\text { (1 and } 2)\end{array}$ & Residual lung damage & $\begin{array}{c}82 \\
(15)\end{array}$ & $\begin{array}{r}0.14 \\
(18)\end{array}$ & $\begin{array}{c}99 \\
(20)\end{array}$ \\
\hline
\end{tabular}

${ }^{*} \mathrm{G}$, gestation at birth; CRP, C-reactive protein; I/TI, immature:total neutrophil index; MTFA, monocyte tissue factor antigen; and CSF, cerebrospinal fluid. Numbers in parentheses indicate day of age on which investigation result was obtained.

produce the high percentages of strongly positive cells observed in the babies with proven infection and lower percentages of strongly positive cells in the baby affected by Rhesus IHD.

TF procoagulant activity is not normally demonstrable until at least $2 \mathrm{~h}$ after endotoxin exposure at $37^{\circ} \mathrm{C}$, and the cells in this study were kept at $4^{\circ} \mathrm{C}$ during cell washings, the antibody labeling being the only procedure carried out at room temperature. The total preparative phase was completed in less than $5 \mathrm{~h}$ from the time of sampling.

It is very likely that the four babies studied within $4 \mathrm{~d}$ of infection screening investigations, who were in the group of babies strongly suspected of being infected and in whom high percentages of monocytes were positive, were in fact infected. One was recovering from an episode of necrotizing enterocolitis 
experienced 2 wk previously when he unexpectedly collapsed, requiring ventilatory support. One had been tachypneic from birth for no identified reason, one developed diarrhea and vomiting, and one had been asphyxiated perinatally, was febrile postnatally, had 40 white cells in his cerebrospinal fluid, and made an uneventful recovery with antimicrobial therapy. Confirmation of infection may not have been obtained for several reasons. Cultures for mycoplasmas and ureaplasmas were not routinely performed, and the volume of blood available for culture was sometimes small. Lipoglycans from mycoplasmas can induce mononuclear cell TF procoagulant activity (48). Viral cultures were not always performed, and, when they were, only a few specific viruses were sought. Antimicrobials administered to the mother before the birth of her baby may have obviated a positive bacterial isolate in two instances.

A wide range of postnatal ages were encountered in the singly studied, noninfected babies in group II $(2,3,5,6,8,9,14,46$, and $76 \mathrm{~d}$ ). The antigen and enteral endotoxin exposures associated with increasing postnatal age do not appear to be sufficient stimuli to cause many of the circulating blood monocytes to express surface TF strongly.

The results from the monocyte testing obtained within $4 \mathrm{~d}$ of a positive culture, were considered separately from those obtained beyond $4 \mathrm{~d}$ because culture and sequentially performed ancillary infection test results can usefully be evaluated at this time; if monocyte TFA expression were to be used as a predictor of infection, then TFA would have to be detectable within this time frame. If negative, the results of this combination of tests can be of help in deciding whether the infant, started on antimicrobial treatment at the time of initial screening, may reasonably be taken off such treatment; conversely, when infection, although not proven on culture, is strongly suspected on the basis of the ancillary test results, treatment can be continued.

Of interest is the apparent persistence of monocyte positivity after bacterial infections in cases J, K, L, and M. In only one of these babies (case $\mathrm{M}$ ) was any chronic disease evident; this took the form of chronic lung disease after pneumonia. The remaining three had all made uneventful recoveries at the time of sampling. The negative results in the case of Candida septicemia can be attributed to the lack of previous $\mathrm{T}$-cell sensitization to this antigen in the baby concerned. T-cell sensitization and collaboration appear to be prerequisites for the monocyte procoagulant response to Candida (49).

This study has demonstrated that a very high percentage of monocytes from preterm infants can express TF to a degree similar to that of monocytes from term infants when either group is infected with gram-positive or gram-negative bacteria. This capacity is present on $\mathrm{d} 1$ of life and is maintained with increasing maturity (Staphylococcus epidermidis on d 26 in a 25 -wk gestation baby, Klebsiella on d 40 in a 32 -wk gestation baby). The constraints on permitted blood sampling for this study prevented us from comparing biologic procoagulant activity with TFA expression. An extrinsic pathway inhibitor has been identified in adult serum (50), and a potent placental inhibitor has been described (51). What level is present in neonates at differing gestations and how its presence might affect TF procoagulant activity or antigen detection remains to be discovered. Only one of the cases with sepsis and TFA-positive monocytes had coagulation test results that were abnormal for the gestational and postnatal age of the baby; they were compatible with a diagnosis of disordered proteolysis.

From this investigation, it is not possible to make any general statement as to whether viral infections in the neonate induce TFA expression. In only one case of proven viral disease, an acquired infection with two strains of cytomegalovirus (case $J$ ), were $99 \%$ of the monocytes positive; however, at the time, blood cultures were positive for coagulase-negative staphylococci. Further studies are required during viral infections, although these infections are thought to be rare during the 1 st wk of life; information is also required during the course of the more common stressful conditions such as surfactant-deficient respiratory distress syndrome before the value of monocyte $\mathrm{TF}$ measurement as an indicator of the presence of infection can be fully evaluated. In conclusion, we have shown that when more than $60 \%$ of the blood monocytes of an infant are found to be positive for surface TFA as defined by this method there appears to be a high likelihood of the infant being infected or, by inference, of having biologically significant blood levels of endotoxin.

Acknowledgments. The authors thank Dr. A. Pinching and the Department of Immunology for their assistance in undertaking the flow cytometry studies, Dr. T. Lissauer and the staff of the Winnicott Baby Unit for their collaboration in the collection of samples for the study, and Alick Stephens for preparing the immunoblots.

\section{REFERENCES}

1. Osterud B, Rapaport SI 1977 Activation of factor IX by the reaction product of tissue factor and factor VII: additional pathway for initiating blood coagulation. Proc Natl Acad Sci USA 74:5260-5264

2. Niemetz J 1972 Coagulant activity of leukocytes. Tissue factor activity. J Clin Invest 51:307-313

3. Rivers RPA, Hathaway WE, Weston WL 1975 The endotoxin-induced coagulant activity of human monocytes. Br J Haematol 30:311-316

4. Prydz H, Allison AC 1978 Tissue thromboplastin activity of isolated human monocytes. Thromb Haemost 39:582-591

5. Levy GA, Schwartz BS, Edgington TS 1981 The kinetics and metabolic requirements for direct lymphocyte induction of human procoagulant monokines by bacterial lipopolysaccharide. J Immunol 127:357-363

6. Prydz H, Allison AC, Schorlemmer HU 1977 Further link between complement activation and blood coagulation. Nature 270:173-174

7. Rothberger H, Zimmerman TS, Spiegelberg HL, Vaughan JH 1977 Leukocyte procoagulant activity: enhancement of production in vitro by $\mathrm{IgG}$ and antigen-antibody complexes. J Clin Invest 59:549-557

8. Lyberg T, Prydz H 1982 Thromboplastin (Factor III) activity in human monocytes induced by immune complexes. Eur J Clin Invest 12:229-234

9. Schwartz BS, Edgington TS 1981 Immune complex-induced human monocyte procoagulant activity. I. A rapid unidirectional lymphocyte-instructed pathway. J Exp Med 154:892-906

10. Schwartz BS, Levy GA, Edgington TS 1982 Immune complex-induced human monocyte procoagulant activity. I1. Cellular kinetics and metabolic requirements. J Immunol 128:1037-1042

11. Weymes B, Rivers RPA 1977 The clot-promoting (tissue factor) activity of human monocytes following exposure to anti-D coated erythrocytes. Pediatr Res 11:1018(abstr)

12. Rothberger H, Lee T-K, Dunne J, Zimmerman TS 1982 Increases of leukocyte tissue factor activity stimulated by red cells sensitized with human blood group alloantibodies. Thromb Res 27:537-547

13. Prydz H, Lyberg T, Deteix P, Allison AC 1979 In vitro stimulation of tissue thromboplastin (Factor III) activity in human monocytes by immune complexes and lectins. Thromb Res 15:465-474

14. Lyberg T, Prydz H 1981 Phorbol esters induce synthesis of thromboplastin activity in human monocytes. Biochem J 194:699-706

15. Edwards RL, Rickles FR 1980 The role of human T cells (and T cell products) for monocyte tissue factor generation. J Immunol 125:606-609

16. Geczy CL. Hopper KE 1981 A mechanism of migration inhibition in delayedtype hypersensitivity reactions. II. Lymphokines promote procoagulant activity of macrophages in vitro. J Immunol 126:1059-1065

17. Levy GA, Leibowitz JL, Edgington TS 1981 Induction of monocyte procoagulant activity by murine hepatitis virus type 3 parallels disease susceptibility in mice. J Exp Med 154:1150-1163

18. Rothberger H, Zimmerman TS, Vaughan JH 1978 Increased production and expression of tissue thromboplastin-like procoagulant activity in vitro by allogeneically stimulated human leukocytes. I Clin Invest 62:649-655

19. Levy GA, Edgington TS 1980 Lymphocyte cooperation is required for amplification of macrophage procoagulant activity. J Exp Med 151:1232-1244

20. Van Ginkel CJW. Zeijlemaker WP, Stricker LAM. Oh JIH, Van Aken WG 1981 Enhancement of monocyte thromboplastin activity by antigenically stimulated lymphocytes. A link between immune reactivity and blood coagulation. Eur J Immunol 11:579-583

21. Helin NJ, Fox RI, Edgington TS 1983 The instructor cell for the human monocyte procoagulant monocyte response to bacterial lipopolysaccharide is a Leu-3a+ $T$ cell by fluorescence-activated cell sorting. $J$ Immunol $131: 749-752$

22. Helin NJ, Edgington TS 1983 Allogeneic induction of human T cell-instructed monocyte procoalugant response is rapid and is elicited by HLA-DR. J Exp Med 158:962-975

23. Gregory SA, Edgington TS 1985 Tissue factor induction in human monocytes. Two distinct mechanisms displayed by different alloantigen-responsive $\Upsilon$ cell clones. J Clin Invest 76:2440-2445

24. Schwartz BS 1985 Antigen-induced monocyte procoagulant activity. Requirement for antigen presentation and histocompatibility leukocyte antigen-DR molecules. J Clin Invest 76:970-977 
25. Niemetz J, Marcus AJ 1974 The stimulatory effect of platelets and platelet membranes on the procoagulant activity of leukocytes. J Clin Invest 54:1437-1443

26. Janco RL, Morris P 1983 Serum augments the generation of monocyte procoagulant stimulated by bacterial lipopolysaccharide or chemotactic fragments of C5. Thromb Res 32:73-86

27. Muhlfelder TW, Niemetz J, Kreutzer D, Beebe D, Ward PA, Rosenfeld SI $1979 \mathrm{C} 5$ chemotactic fragment induces leukocyte production of tissue factor activity. J Clin Invest 63:147-150

28. Rivers RPA, Hathaway WE 1975 Studies on tissue factor activity and production by leukocytes of human umbilical cord and adult origin. Pediatr Res 9:167-171

29. Tsao BP, Fair DS, Curtiss LK, Edgington TS 1984 Monocytes can be induced by lipopolysaccharide-triggered $T$ lymphocytes to express functional factor VII/VIIa protease activity. J Exp Med 159:1042-1057

30. Niemetz J 1972 The role of protein synthesis on the generation of tissue factor activity by leukocytes. Proc Soc Exp Biol Med 139:1276-1279

31. Lyberg T 1984 Intracellular signal mechanisms in induction of thromboplastin synthesis. Haemostasis 14:393-399

32. Dean RT, Leon P, Rossi BC 1984 Regulation of procoagulant factors in mononuclear phagocytes. Haemostasis 14:412-421

33. Lyberg T 1983 Effect of cyclic AMP and cyclic GMP on thromboplastin (Factor III) synthesis in human monocytes in vitro. Thromb Haemost 50:804-809

34. Lyberg T 1984 Clinical significance of increased thromboplastin activity on the monocyte surface: a brief review. Haemostasis 14:430-439

35. Miller CL, Graziano C, Lim RC, Chin M 198! Generation of tissue factor by patient monocytes: correlation to thromboembolic complications. Thromb Haemost 46:489-495

36. Blackowski SA, Zacharski LR, Beck JR 1986 Postoperative elevation of human peripheral blood monocyte tissue factor coagulant activity. J Lab Clin Med 108:117-120

37. Courillon-Mallet A, Bevilacqua M, Wautier J-L, Dervichian M, Cattan D, Caen J 1986 Increased procoagulant response of monocytes from patients with familial mediterranean fever. Thromb Haemost 56:211-213
38. Lyberg T, Prydz N, Baklien K, Hoyeraal HM 1982 Effect of immune complexcontaining sera from patients with rheumatic diseases on thromboplastin activity of monocytes. Thromb Res 25:193-202

39. Van Ginkel CJW Thorig L, Thompson J Oh JHH Van Aken WG 1979 Enhancement of generation of monocyte tissue thromboplastin by bacterial phagocytosis: possible pathway for fibrin formation on infected vegetations in bacterial endocarditis. Infect Immun 25:388-395

40. Osterud B. Flaegstad T 1983 Increased tissue thromboplastin activity in monocytes of patients with meningococcal infection: related to an unfavourable prognosis. Thromb Haemost 49:5-7

41. Oian P, Omsjo I, Maltau JM, Osterud B 1985 Reduced thromboplastin activity in blood monocytes and reduced sensitivity to stimuli in vitro of blood monocytes from pregnant women. Br J Haematol 59:133-137

42. Nemerson Y 1968 The phospholipid requirement of tissue factor in blood coagulation. J Clin Invest 47:72-80

43. Hvatum M, Prydz H 1969 Studies on tissue thromboplastin: its splitting into two separable parts. Thromb Diath Haemorrh 21:217-222

44. Gonmori H, Takeda Y 1976 Properties of human tissue thromboplastins from brain, lung, arteries and placenta. Thromb Haemost 36:90-103

45. Cuatrecasas P 1970 Protein purification by affinity chromatography. J Biol Chem 245:3059-3065

46. Boyum A 1968 Isolation of mononuclear cells and granulocytes from human blood. Scand J Clin Lab Invest 21(suppl 97):77-89

47. Schiefele DW, Fussell S, Olsen E 1984 Bacterial endotoxins in umbilical cord blood of neonates. Biol Neonate 45:119-124

48. Miragliotta G, Barone G, Monno RA, Fumarola D. Smith PF 1987 Induction of procoagulant activity in human leukocytes with lipoglycans from mycoplasmas. J Clin Microbiol 25:1295-1297

49. Schwartz BS, Reitnauer PJ, Hank JA, Sondel PM 1985 A human T cell clone that mediates the monocyte procoagulant response to specific sensitizing antigen. J Clin Invest 76:1279-1282

50. Broze GJ, Miletich JP 1987 Characterization of the inhibition of tissue factor in serum. Blood 69:150-155

51. Kondo S. Noguchi M, Funakoshi T, Fujikawa K, Kisiel W 1987 Inhibition of human Factor VIla: tissue factor activity by placental anticoagulant protein. Thromb Res 48:449-459 